\title{
Pliyosen Dorutay Havzası (Özalp-Van) Gölsel Çökellerinin Yapısal ve Sedimantolojik Özellikleri
}

\author{
Structural and Sedimentological Properties of Lacustrine Deposits in \\ Pliocene Dorutay Basin (Özalp-Van)
}

\author{
SERKAN ÜNER ${ }^{1 *}$, CANSU OKULDAŞ ${ }^{1}$, AHMET VEDAT YILMAZ1 \\ ${ }^{1}$ Yüzüncü Yı Üniversitesi, Jeoloji Mühendisliği Bölümü, 65080, Zeve Kampüsü, VAN \\ Geliș (received) : 12 Ocak (January) 2015 \\ Kabul (accepted) : 09 Mart (March) 2015
}

Öz

Arap ve Avrasya Plakaları arasında gelișen çarpıșma, Miyosen ve sonrasında Van Gölü ve çevresinde birçok dağ arası havzanın olușumuna sebep olmuștur. Bu havzalardan birisi de Van'ın Özalp ilçesinde bulunan Pliyosen Dorutay Havzası'dır. Karbonifer yașlı metamorfikler ve Kretase ofiyolitlerinden olușan temel kayaçlar üzerinde uyumsuz olarak gözlenen Pliyo-Kuvaterner yașlı gölsel çökeller, bu dönemde bölgede bulunan geniș yayılımlı bir gölün varlığını ișaret etmektedir. Deniz seviyesinden 2060 m yükseklikte ve 150 km² yayılıma sahip olan bu eski gölün sınırları, gölsel çökeller içerisindeki kıyı fasiyesleri yardımıyla belirlenmiștir. Gölsel çökellerin, çökelme alt ortamlarının ve ortam koșullarının anlașılması için sedimanter fasiyes özellikleri incelenmiș ve bölgede 8 adet sedimanter fasiyes ile sığ göl ve gölsel kıyı ortamını temsil eden 2 adet fasiyes birlikteliği ayırt edilmiștir.

Dorutay Havzası tektonizmanın oldukça aktif olduğu bir bölgede yer almaktadır. Gerek havza kenarlarında, gerekse çökel dolgusunda gözlenen faylar, havzanın jeolojik evriminde önemli rol oynamaktadır. Özellikle bu çalıșmada isimlendirilen Çırakköy Fayı, bölgenin kapalı havzadan açık havza koșullarına geçișinin ana sebebidir. Deprem kayıtları ve jeomorfolojik veriler, havzanın tektonik açıdan günümüzde de aktif olduğunu göstermektedir.

Anahtar Kelimeler: Dorutay Havzası, Doğu Anadolu, fasiyes analizi, gölsel çökeller, Özalp-Van, yapısal jeoloji

\begin{abstract}
The collision between the Arabian and Eurasian plates caused to the formation of intramontane basins around Lake Van during and after Miocene. Pliocene Dorutay Basin (Özalp-Van) is one of these basins. Plio-Quaternary lacustrine deposits in the basin, uncomformably overlie the basement rocks composing of Carboniferous aged metamorphic rocks and Cretaceous ophiolites, indicate the existance of a widespread lake in the region at that time. This paleolake was around 2060 meter above the sea level and occupied in $150 \mathrm{~km}^{2}$ area. The boundaries of the paleolake can be determined using shore facies of lacustrine deposits. Sedimentary facies were investigated for understanding the depositional subenvironments and depositional processes of basin fill. Eight sedimentary facies and two facies associations representing to shallow lacustrine and shore subenvironment were recognized.

Dorutay Basin is located on a seismically active region. Faults on boundaries of the basin and the basin fill play an important role on geological evolution of the basin. Especially the activity of Çırakköy Fault named with this study is the main reason of the changing from closed basin condition to open basin. Earthquake records and geomorphological data are showing the recent tectonnic activity of the basin.
\end{abstract}

Keywords: Dorutay Basin, Eastern Anatolia, facies analysis, lacustrine deposits, Özalp-Van, structural geology

* S. Üner

e-posta: suner@yyu.edu.tr 


\section{Giriș}

Arap Plakası'nın Avrasya Plakası'na doğru hareketi, iki plaka arasında bulunan Neotetis Okyanusu'nun kapanmasına ve Serravaliyen'de kıta-kıta çarpıșmasına sebep olmuștur (Şengör ve Yılmaz, 1981; Dewey vd., 1986). Bu sıkıșma rejimi Doğu Anadolu Platosu ile bölgede bulunan Pasinler, Muș ve Van Gölü havzalarını olușturmuștur (Şaroğlu ve Güner, 1979). Doğu Anadolu Platosu'nun güneyinde yer alan Van Gölü Havzası, Geç Pliyosen'de olușmuș ve bölgede etkili olan Kuvaterner volkanizması ile bugünkü șeklini almıștır (Degens vd., 1984). Günümüzden yaklașık 600.000 yıl önce olușan Van Gölü (Stockhecke vd., 2014), deniz seviyesinden 1650 metre yüksekte bulunmaktadır.

Van Gölü Havzası'nın doğu kesiminde, Özalp'a bağlı Dorutay Köyü civarında deniz seviyesinden 2060 m yüksekte gölsel çökeller bulunmaktadır.
Șenel (1987) tarafından Saray Formasyonu olarak adlandırılan çökellerin yașı Pliyo-Kuvaterner olarak kabul edilmektedir (Arni, 1939; Kıraner, 1959; Altınlı, 1966; Saydamer, 1976). Gölsel çökellerin konumu ve deniz seviyesinden yüksekliği incelendiğinde, Pliyosen'de bölgede yaklașık 900 km²'lik drenaj alanına sahip bir kapalı havzanın bulunduğu belirlenmiștir (Șekil 1). İlk defa bu çalışmada isimlendirilen, tektonik kontrollü Dorutay Havzası'nın, sedimantolojik ve yapısal özelliklerinin belirlenmesi ve jeolojik gelișiminin ortaya konulması bu çalıșmanın amacını olușturmaktadır.

\section{BÖLGESEL JEOLOJi}

Van Gölü Havzası'nın doğusunda, Türkiye-İran sınırında yer alan Dorutay Havzası, Pliyosen'de olușmaya bașlayan bir sıkıșma havzasıdır. Karbonifer yașlı metamorfikler ve Kretase ofiyolitlerinden olușan bir temel üzerinde bulunan havza,

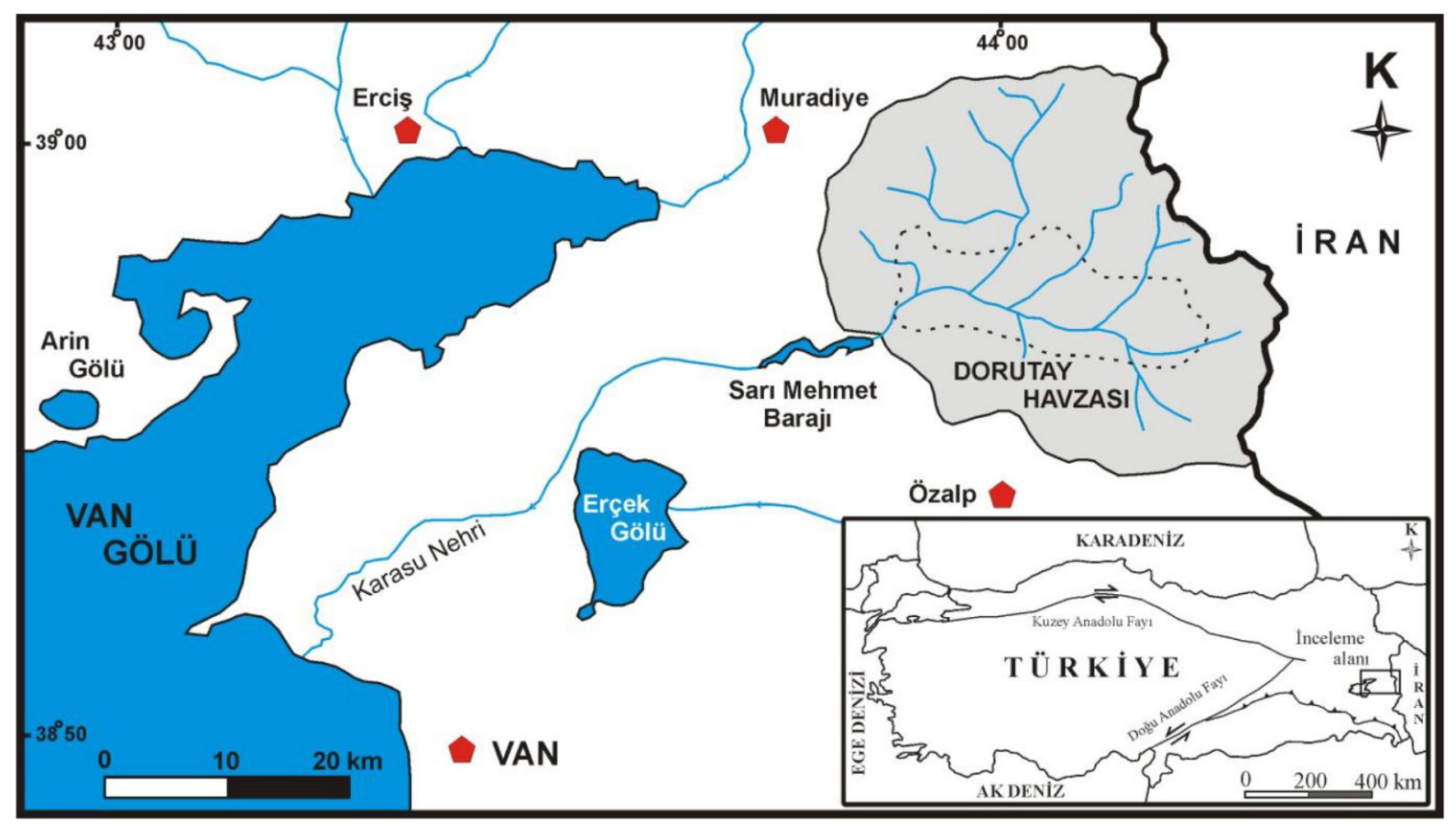

Șekil 1. Dorutay Havzası'nın konumunu gösteren yer bulduru haritası (kesikli çizgi paleogöl alanını göstermektedir).

Figure 1. Location map of the Dorutay Basin (dashed line showing the paleolake area). 
tektonizma ile birlikte Pliyo-Kuvaterner volkanizması tarafından șekillendirilmiștir. Havzanın çökel dolgusu Saray Formasyonu'na ait gölsel çökeller, havza kenarlarında gelișmiș alüvyon yelpazeleri ve Karasu Nehri'nin tașıdığı güncel alüvyonlardan olușmaktadır (Șekil 2).

Doğu Anadolu Platosu ve Van Gölü Havzası'nda, Arap Plakası ile Avrasya Plakası arasındaki çarpıșma sonrası gelișen K-G doğrultulu sıkıșma rejimi hakimdir (Şaroğlu ve Yılmaz, 1986; Koçyiğit vd., 2001; Özkaymak vd., 2011; Koçyiğit, 2013). D-B doğrultulu ters faylar, KB-GD doğrultulu sağ yönlü ve KD-GB doğrultulu sol yönlü doğrultu atımlı faylarla ile K-G doğrultulu normal faylar ile temsil edilen bu rejim, Dorutay Havzası'nda da benzer yapısal unsurlar sunmaktadır (Șekil 2).

\section{YÖNTEM}

Dorutay Havzası'nın sınırlarının belirlenmesi ve bölgenin jeoloji haritasının hazırlanması çaıșmanın ilk așamasını olușturmaktadır. Sonrasında Dorutay ve Dönerdere köyleri arasında gözlenen gölsel çökellerin deniz seviyesinden yükseklikleri ve konumları belirlenmiștir. Gölsel çökel istifi, en alt kısımdan bașlayarak yukarıya doğru litofasiyeslere ayrılmıș, bunlar arasındaki yanal ve düșey geçișler belirlenmiștir. Tanımlamalar ilgili literatür ile karșılaștırılarak, birimlerin oluștuğu alt ortamlar ve ortam koșulları ortaya konulmuștur. Havza kenarlarında ya da gölsel istif içerisinde gözlenen fayların karakterleri ve güncel aktiviteleri belirlenmiștir. Ölçülen sedimanter fasiyesler yardımıyla belirlenen paleoortamların dizilimi ve havzadaki fayların yapısal özellikleri beraber değerlendirilerek, Dorutay Havzası'nın Pliyosen ve sonrasındaki jeolojik gelișimi yorumlanmıștır.

\section{DORUTAY HAVZASI}

Dorutay Havzası, Van Gölü'nün KD'sunda, yaklașık 900 km²'lik geniș bir drenaj alanına sahip bir dağ arası havzasıdır. Kuzeyde Yücelen, Cacur, Balçıklı, Çayır ve Oymaklı dereleri tarafından beslenen Karasu Nehri havzanın en önemli akarsuyudur. Havza batısından dar bir kanal yardımıyla Van Gölü'ne doğru yol alan Karasu Nehri üzerinde, Dorutay Havzası'nın hemen batısında Sarı Mehmet Barajı bulunur. Havza güneyden sağ yanal doğrultu atımlı fay karakterindeki Dorutay Fayı, batıdan ise Çırakköy batısında bulunan normal fay ile sınırlandırımaktadır (Șekil 2).

\section{Dorutay Havzası Fayları}

Dorutay Havzası'nın doğusunda sağ yanal doğrultu atımlı Hasan Timur Gölü Fayı ve Dorutay Fayı yer alır. Türkiye Diri Fay Haritası'nda (Emre vd., 2012) Holosen fayı olarak tanımlanan bu faylardan Hasan Timur Gölü Fayı, kuzeyde Yukarı Balçıklı Köyü civarından başlayıp KB-GD doğrultulu olarak İran sınırı içlerine kadar yaklașı 20 km devam eder. Bu faya paralel konumdaki Dorutay Fayı ise Dönerdere ve Dorutay köyleri arasında yaklaşık $10 \mathrm{~km}$ takip edilebilmektedir. Havza kenarlarında bu faylar dıșında, ilk kez bu çalıșma ile adlandırılan ve tanımlanan Çırakköy ve Aksorguç fayları yer alır. K-G doğrultulu Çırakköy Fayı, kuzeyde Așağıakçagül Köyü'nden başlayıp, havza dıșında Kırkçalı Köyü'ne kadar 12 km boyunca uzanan, doğuya eğimli bir normal faydır. D-B uzanımlı Aksorguç Fayı ise, Seydibey ve Aksorguç köyleri boyunca yaklaşık 7 km takip edilebilen, kuzeye eğimli, bindirme karakterli bir faydır. Çırakköy ve Aksorguç fayları, arazi çalıșmalarında fay sarplıkları önünde dizilen alüvyon yelpazeleri yardımıyla takip edilebilmektedir. Havza gölsel çökelleri içerisinde küçük ölçekli bindirme faylarına ve ters faylara rastlanmaktadır (Șekil 3a-b). Yaklașık D-B gidișli bu faylar K-G yönlü sıkıșma rejimini temsil etmektedir.

Dorutay Havzası ve yakın çevresinde aletsel dönemde meydana gelen depremlere ait kayıtlar (KOERI, 2014) uydu görüntüsü üzerine yerleștirildiğinde, son yıllarda özellikle Çırakköy Fayı'nın doğrultusuna paralel çizgisellik gösteren sismik etkinliğin varlığı gözlenmektedir (Șekil 3c). Havzanın diğer önemli yapısal unsurları olan Hasan Timur Gölü Fayı ve Dorutay Fayı üzerinde ise, nispeten düșük aktivite gözlenmektedir. Ak- 


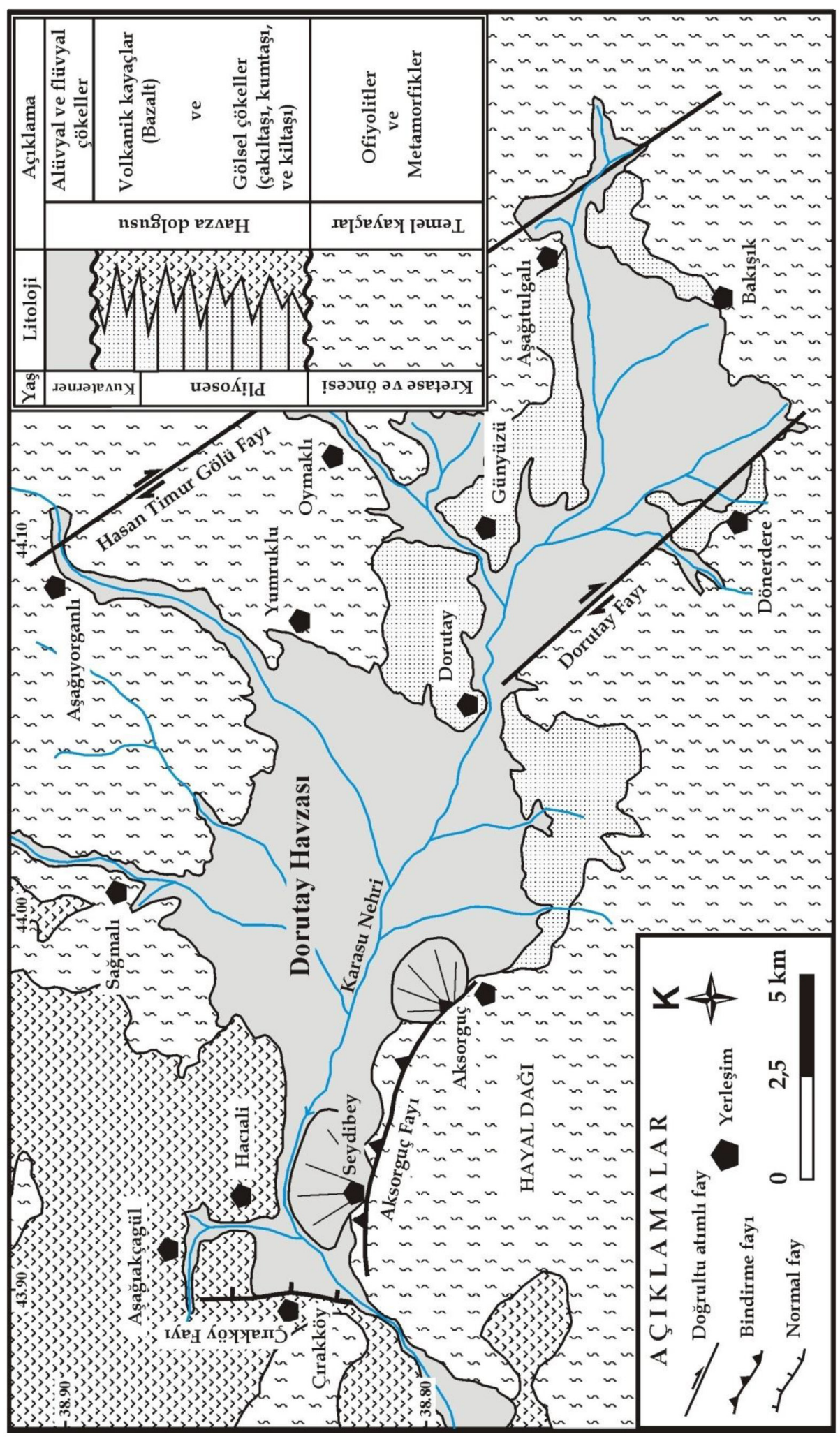

Șekil 2. Dorutay Havzası'nın basitleștirilmiș jeoloji haritası (Șenel, 1987; Sümengen, 2008'den değiștirilmiștir). Figure 2. Simplified geological map of the Dorutay Basin (modified from Șenel, 1987; Sümengen, 2008). 


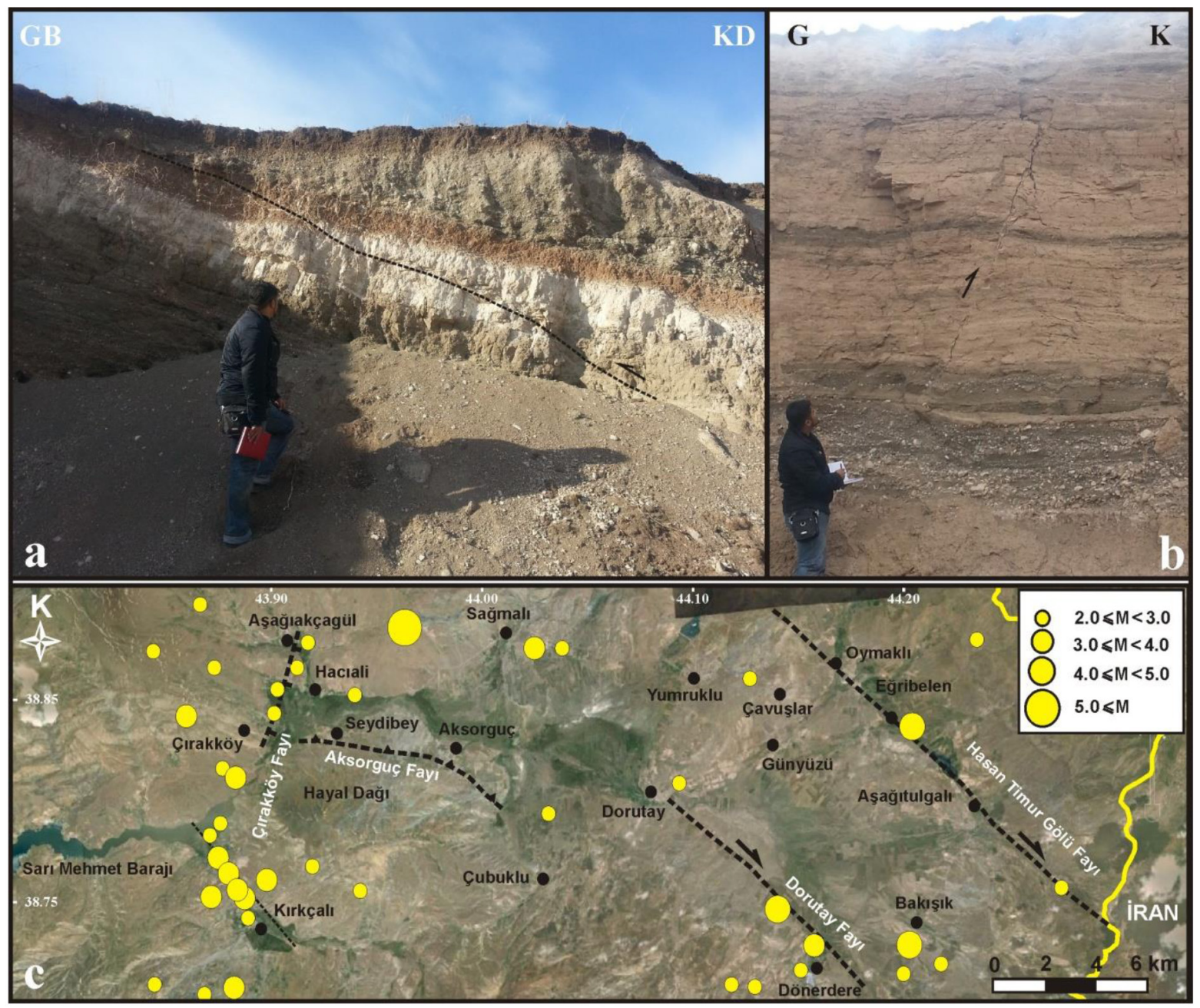

Șekil 3. Dorutay Havzası gölsel çökellerinde belirlenen; bindirme fayı (a) ve ters fay (b). Dorutay Havzası ve yakın çevresinde aletsel dönemde meydana gelmiș olan $M=2$ ve üzeri büyüklüklerdeki depremlerin (KOERI, 2014) dıș merkezlerini gösteren Google Earth uydu görüntüsü (c).

Figure 3. Faults were determined in lacustrine deposits of Dorutay Basin; thrust fault (a) and reverse fault (b). Earthquake epicenters with magnitude $M=2$ and higher on Google Earth satellite image from Dorutay Basin and surrounding area in instrumental period (KOERI, 2014) (c).

sorguç Fayı kuzeyinde, Karasu Nehri kanalında belirlenen yer değiștirmeler, bölgesel tektonik aktivitesinin bir bașka göstergesidir.

\section{Havza Gölsel Çökellerin Fasiyes Özellikleri}

Gölsel çökeller Dorutay Havzası'nın güneyinde, Dorutay ve Dönerdere köyleri arasında mostra vermektedir. Havzanın jeolojik gelișiminin belirlenebilmesi için gölsel çökeller; litolojisi, dokusal özellikleri, tane boyu, tane șekli, bağlayıcı malzemesi, sedimanter yapıları, geometrisi ve fosil içeriğine göre 8 adet litofasiyese ve 2 ayrı fasiyes topluluğuna ayrılmıștır (Çizelge 1).

Dönerdere KB'sındaki sedimanter istif, temel kayaçlar üzerinde bulunan paleotoprak katmanı (F1) ile bașlamaktadır (Șekil 4a). Bu birim üzerinde bulunan delta düzlüğü-gölsel kıyı ortamı çökelleri (F2) bölgede genişlemekte olan 
Çizelge 1. Dorutay Havzası gölsel çökellerinde belirlenen litofasiyeslere ait tanımlamalar ve ortamsal yorumlar Table 1. Lithofacies and depositional environments of lacustrine deposits in Dorutay Basin

\begin{tabular}{lll}
\hline Fasiyesler & Açıklamalar & Yorum \\
\hline Fasiyes 1 & Fasiyesin ölçülebilir kalınlığı 140 cm'dir. Pekișmemiș & Bitki kök izlerinin ve kaliș seviyelerinin \\
Paleotoprak (F1) & malzemeden olușan, kahverenkli birimin tabanı & bulunması sebebiyle birim paleotoprak \\
& gözlenmemektedir. Üst seviyelerinde okside olmuș & olarak isimlendirilmiștir (Miall, 1978). \\
& çakıllar bulunmaktadır. İçerisinde bitki kalıntıları mevcut &
\end{tabular}

Fasiyes 2

Matriks destekli kaba çakıl fasiyesi (F2)

Fasiyes 3 Bitki kök izli çamur fasiyesi (F3)

Fasiyes 4 Matriks destekli ince çakıl fasiyesi (F4)

Fasiyes 5 Dalga ripıllı kum fasiyesi (F5)

Fasiyes 6 Çapraz tabakalı ince çakıl fasiyesi (F6)

Fasiyes 7 Çapraz tabakalı kaba kum-ince çakıl fasiyesi (F7)

Fasiyes 8 Karbonat fasiyesi (F8) olan birim \% 5'lik $\mathrm{HCl}$ ile zengin köpürmektedir.

Fasiyesin ölçülebilir kalınlığı 50 cm'dir. Birim, yarı yuvarlak, disk șekilli ve orta-iyi boylanmıș, maksimum $5 \mathrm{~cm}$, minimum $0,5 \mathrm{~cm}$ ve ortalama $1 \mathrm{~cm}$ tane boyuna sahip çakıllardan olușmaktadır. Çakıllar kaba kum-ince çakıl boyutlu bir matriks ile bağlanmıștır.

Ölçülebilir kalınlığı $35 \mathrm{~cm}$ olan fasiyesin alt ve üst seviyeleri geçișli olarak gözlenmektedir. İnce kum-siltkil ardalanmasından olușan birim açık kahverenklidir. İçerisinde bitki kök kalıntıları bulunan birimde yüzer biçimde çakıllar gözlenmektedir.

Fasiyesin görünür kalınlığı 150 cm'dir. Genel olarak gri renge sahip olan birim köşeli-yarı yuvarlak ve kötü boylanmış çakıllardan oluşur. Çakılların tane boyutu maksimum $11 \mathrm{~cm}$, minimum $0.5 \mathrm{~cm}$ 'dir. Çakıllar kaba kum boyutu bir matriks ile bağlanmıștır. Çakıllı birim arasında bulunan kumlu seviyelerde küçük ölçekli çapraz tabakalar mevcuttur. Birim içerisinde ince organik kalıntı seviyeleri ve kırılmıș pelesipoda kavkı parçaları bulunmaktadır.

Bej-kahverenge sahip birim ince-kaba kum boyutu, zayıf pekișmiș sedimanlardan olușmaktadır. Ortakalın tabakalı birim içerisinde dalga ripılları ve kırılmıș gastropoda-pelesipoda kavkı parçaları bulunmaktadır. Tabanı keskin, tavanı așındırmalı olan birim içerisinde çakıl cepleri gözlenmektedir. Kumlu ve çakıllı seviyelerde paleoakıntı yönü veren düzlemsel çapraz tabakalar ve biniklik (imbrikasyon) göze çarpmaktadır.

Fasiyes 3 metre görünür kalınlığa ve 2 metre yanal yayılıma sahiptir. Çapraz tabakalanma ve biniklik gösteren, iyi boylanmış, yuvarlak ve yassı çakıllardan oluşmaktadır. Ortalama 5-15 cm katmanlardan oluşan birim yanında bulunan kumlu birim ile girik halde bulunmaktadır. Sedimanter yapılara göre paleoakıntı yönü GD olarak belirlenmiştir. Yer yer okside seviyeler gözlenmektedir.

Orta-kalın tabakalı kaba kum-ince çakıl ardalanmasından olușan birimde pelesipoda kavkı parçaları bulunmaktadır. Orta-iyi boylanma gösteren çakıllarda yer yer normal derecelenme gözlenmektedir. Ortalama 2-3 cm'lik tane boyutuna sahip çakıllarda, tekne türü çapraz tabakalanma ve biniklik (imbrikasyon) gözlenmektedir. Birimin tabanı așındırmalı, tavanı geçișlidir.

Kirli beyaz-gri renkli karbonat seviyesi. Karbonat seviyesinin kalınlığı yanal olarak değișim göstermektedir.
Disk șekilli, yarı yuvarlak çakıllar birimin dalga etkisinin fazla olduğu bir kıyı ortamında depolandığını göstermektedir (Massari ve Parea, 1988).

Bitki kök izleri bulunan, ince taneli birimin bataklık ortamında depolandığı düșünülmektedir (Galloway, 1976).

Pelesipoda kavkı parçaları içeren köșeliyarı yuvarlak ve kötü boylanmıs çakıllar bu fasiyesin kıyı̈nü ortamında gelișen moloz akması ile oluștuğunu göstermektedir (Postma, 1984).

Dalga ripılları, fosil kavkı parçaları ve az miktarda çakıl bulunması bu fasiyesin sığ su koșullarında depolandığını göstermektedir (Reineck ve Singh, 1973).

Çapraz tabakalanma, yandaki kumlu birimle giriklik ve çakıllarda gözlenen biniklik kıyıya paralel gelişen bir kıyıdili șeklinde yorumlanmıștır (Castelle vd., 2006).

Çakıllardaki biniklik, çapraz tabakalanma ve kırılmıș pelesipoda kavkı parçaları birimin yüksek enerjili bir kıyı ortamında çökeldiğini göstermektedir (Postma, 1990).

Gölün çekilmesi ile olușan gölcüklerdeki suyun buharlașması ile olușan karbonat çökelimi. Katman kalınlığı gölcüklerin taban morfolojisine bağlı olarak değișmektedir. 


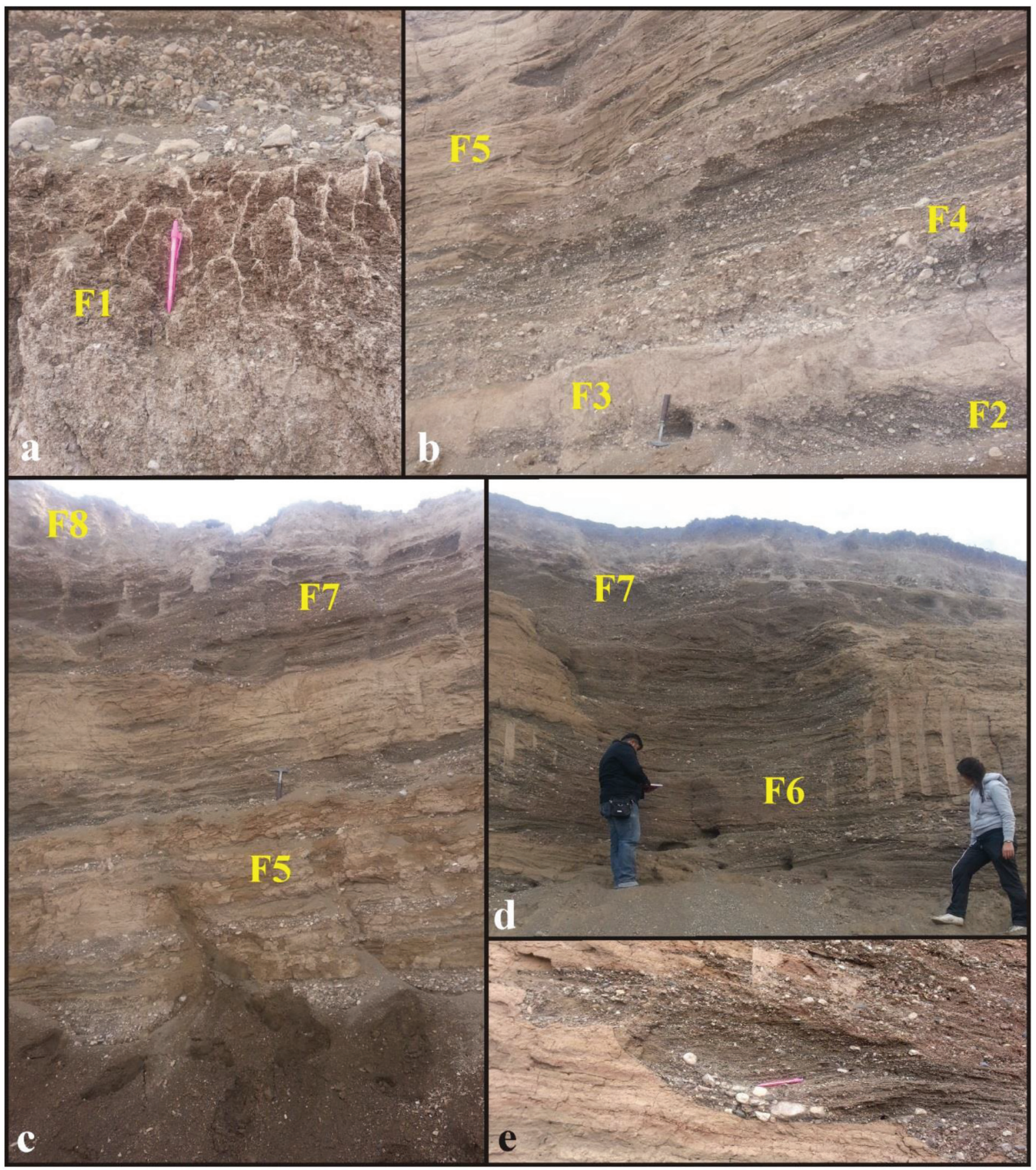

Șekil 4. a-d) Dorutay Havzası gölsel çökellerinde belirlenen 8 litofasiyesin arazi görüntüsü, e) Fasiyes 6'da gözlenen çapraz tabakalanma.

Figure 4. a-d) Field photographs of eight facies encountered within lacustrine deposits of Dorutay Basin, e) crossbedding from Facies 6. 
bir gölün varlığını göstermektedir. Yanal ve düșey olarak bu birimlerle beraber bulunan, kahve renkli, organik maddece zengin bataklık ortamı çökelleri (F3) ile sualtı koșullarında gelișen moloz akıș çökelleri (F4), kıyı ortamına malzeme tașıyan bir delta gelișimi șeklinde yorumlanabilir. Bu çökeller üzerinde bulunan dalga ripılları ve kavkı kalıntıları içeren, yatay katmanlı birim (F5), dalga tabanı içerisinde, sığ gölsel ortam koșullarında meydana gelen sedimantasyonu ișaret etmektedir (Șekil 4b).

İstifin üst kesimlerinde bulunan ve yaklaşık olarak paleo-göl kıyısına paralel gelișim gösteren çakıllı birim (F6), her iki taraftan da kumlu, sığ gölsel birimlerle (F5) girik halde bulunmaktadır (Șekil 4c). Çapraz tabakalar ve biniklenmeler yardımıyla, GD yönlü paleoakıșı gösteren bu birim, kıyı boyunca gelişen bir kıyı dilinin varlığını göstermektedir (Șekil 4d-e). Gölsel istif, yüksek enerjili kıyı koșullarını gösteren çakıllı-kumlu çökeller (F7) ve bunların üzerine gelen karbonat katmanı ile (F8) son bulmaktadır.

İncelenen istiften elde edilen veriler, sığ göl ve gölsel kıyı ortam koşullarının egemen olduğu bir çökelme ortamını göstermektedir. Göl seviyesindeki küçük ölçekli oynamalar sebebiyle, gölsel kıyı çökelleri ile sığ gölsel ortam çökellerinin ardalanmalı olarak depolandığı gözlenmektedir (Șekil 5).

\section{DORUTAY HAVZASI'NIN JEOLOJIK GELIȘiMi}

Dorutay Havzası, Pliyosen'de kapalı havza olarak olușmuștur. Türkiye-İran sınırına kadar uzanan geniş drenaj alanı, havzada su depolanmasını sağlamıștır. Fasiyes analizi sonucunda, gölsel kıyı çökellerinin konumları ve deniz seviyesinden yükseklikleri temel alınarak, havza içerisinde yüzey alanı 150 km²'yi bulan bir gölün oluștuğu belirlenmiștir (Șekil 6a). Düșük hacime sahip tüm göllerde olduğu gibi, Dorutay Havzası'nda bulunan göl de iklimsel değișimlerden önemli şekilde etkilenmiştir. Jeolojik istifte, çökelme ortamlarında gözlenen değişimler, göl su seviyesindeki küçük ölçekli mevsimsel oynamaları ve sonuçlarını temsil etmektedir. Kuvaterner'de Dorutay Havzası'ndaki gölsel ortam, su seviyesindeki azalma sonucunda yerini flüvyal ortama bırakmıștır.

Göl su seviyesindeki alçalma iklimsel faktörlerle açıklanabilirken, bölgenin kapalı havza konumunu kaybetmesi iklim ile bağlantılı değildir. Havza batısında, Çırakköy'de bulunan K-G doğrultulu ve doğuya eğimli normal fayın, havza dışına bir boşaltım kanalı açtığı ve gölün bu kanal sayesinde boșaltıldığı kanısındayız. Sonrasında Karasu Nehri tarafından kullanılan kanal ile Dorutay Havzası kapalı havza özelliğini kaybetmiș ve Van Gölü Havzası'nı besleyen drenaj ağının bir parçası olmuștur. Günümüzde havzaya Hayal Dağı'ndan aşınan sedimanların olușturduğu alüvyon yelpazeleri ile Karasu Nehri'nin kanal ve tașkın ovası çökelleri depolanmaktadır (Șekil 6b).

\section{SONUÇLAR}

Miyosen sonrası Avrasya ile Arap plakalarının çarpıșma zonunun yakın çevresinde, sıkıșma ürünü havzalar olușmuștur. Bunlardan birisi olan Dorutay Havzası, Pliyosen'de olușmaya bașlayan gölsel ortama ait çökeller ve bu çökeller üzerine depolanan Kuvaterner yașlı alüvyal ve flüvyal çökeller ile temsil edilir. Günümüzde deniz seviyesinden 2060 metre yüksekte bulunan gölsel çökellerin sedimanter fasiyes özellikleri incelendiğinde, bir dönem havzada etkili olan gölsel ortam koșulları hakkında bilgi sahibi olunabilmektedir. Elde edilen verilere göre, Dorutay Havzası'nda gölsel ortamın olușmasında iklimsel faktörler baș rolü oynarken, bölgenin kapalı havza özelliğini kaybetmesinde ise bölgesel tektonizma etkindir.

Çırakköy doğusunda bulunan normal fayın aktivitesi sebebiyle açılan boșaltım kanalı, Dorutay Havzası'nda bulunan gölün yok olmasının sebebidir. Pliyosen'de bölgede Van Gölü'nün henüz bulunmadığı düşünülürse, suyun çok hızlı bir șekilde, bugünkü taban seviyesi (Van Gölü) olan 1650 metrenin de altındaki düșük kotlara doğru ilerlemesiyle yoğun bir așınma gerçekleșmiștir. 


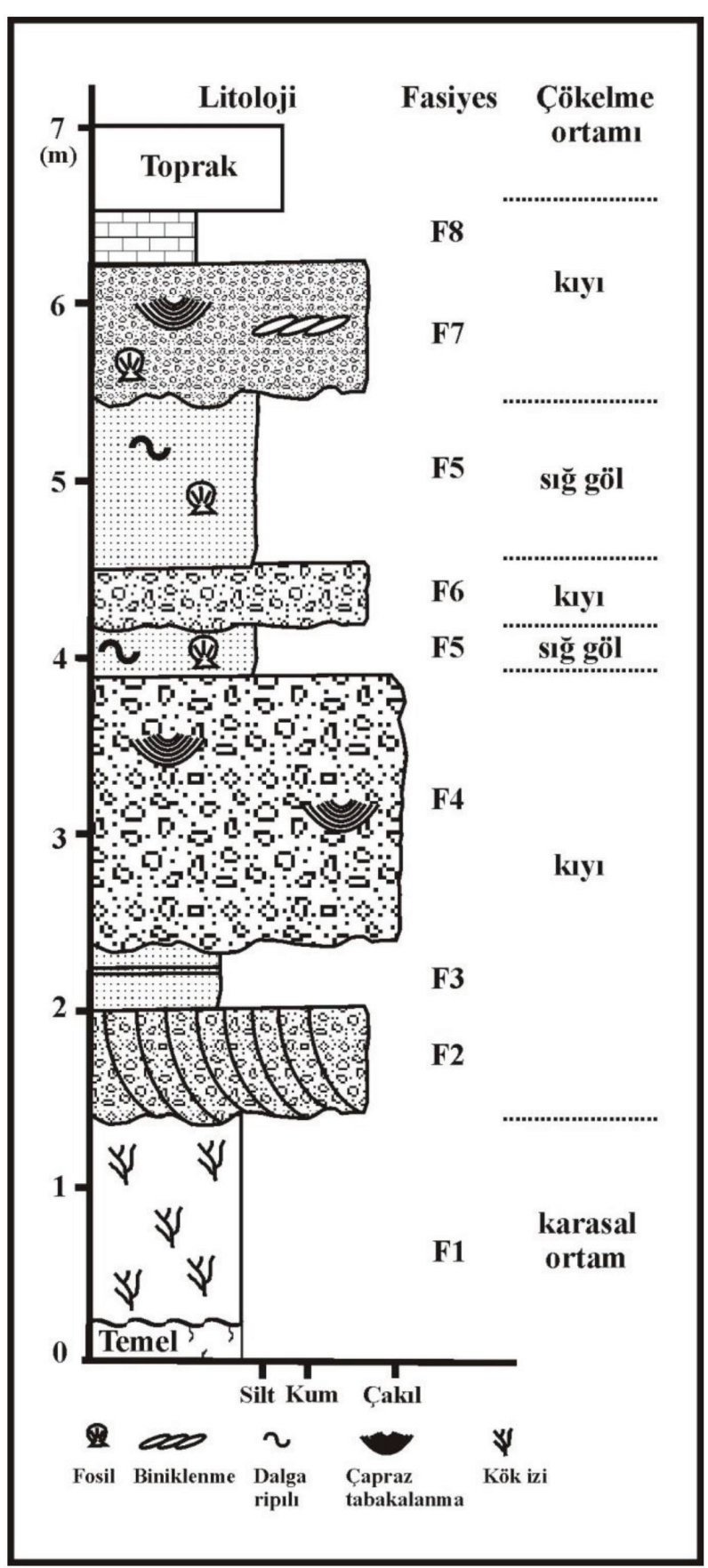

Șekil 5. Sedimanter fasiyeslerin dizilimlerini ve çökelme alt ortamlarını gösteren ölçülü stratigrafik istif.

Figure 5. Measured stratigraphic section showing the sequence of lithofacies and depositional environments.

Kıtı-kıta çarpışma zonunun kuzeyinde bulunan bölgenin hızlı yükselimi (Şengör ve Kidd, 1979; Koçyiğit vd., 2001) așınmanın bir diğer sebebi olarak kabul edilebilir. Dorutay Havzası'nda gölsel çökellere sıkça rastlanmamasının sebebi bu hızlı așınma ile açıklanabilir.
Pliyo-Kuvaterner yașlı havza dolgusu içerisinde gözlenen yapısal unsurlar K-G yönlü sıkıșma rejiminin bölgede Pliyosen sonrasında da devam ettiğinin göstergesidir. Arazi verileri ve deprem kayıtları Dorutay Havzası'nı sınırlayan fayların güncel aktivitesinin açık kanıtıdır. 


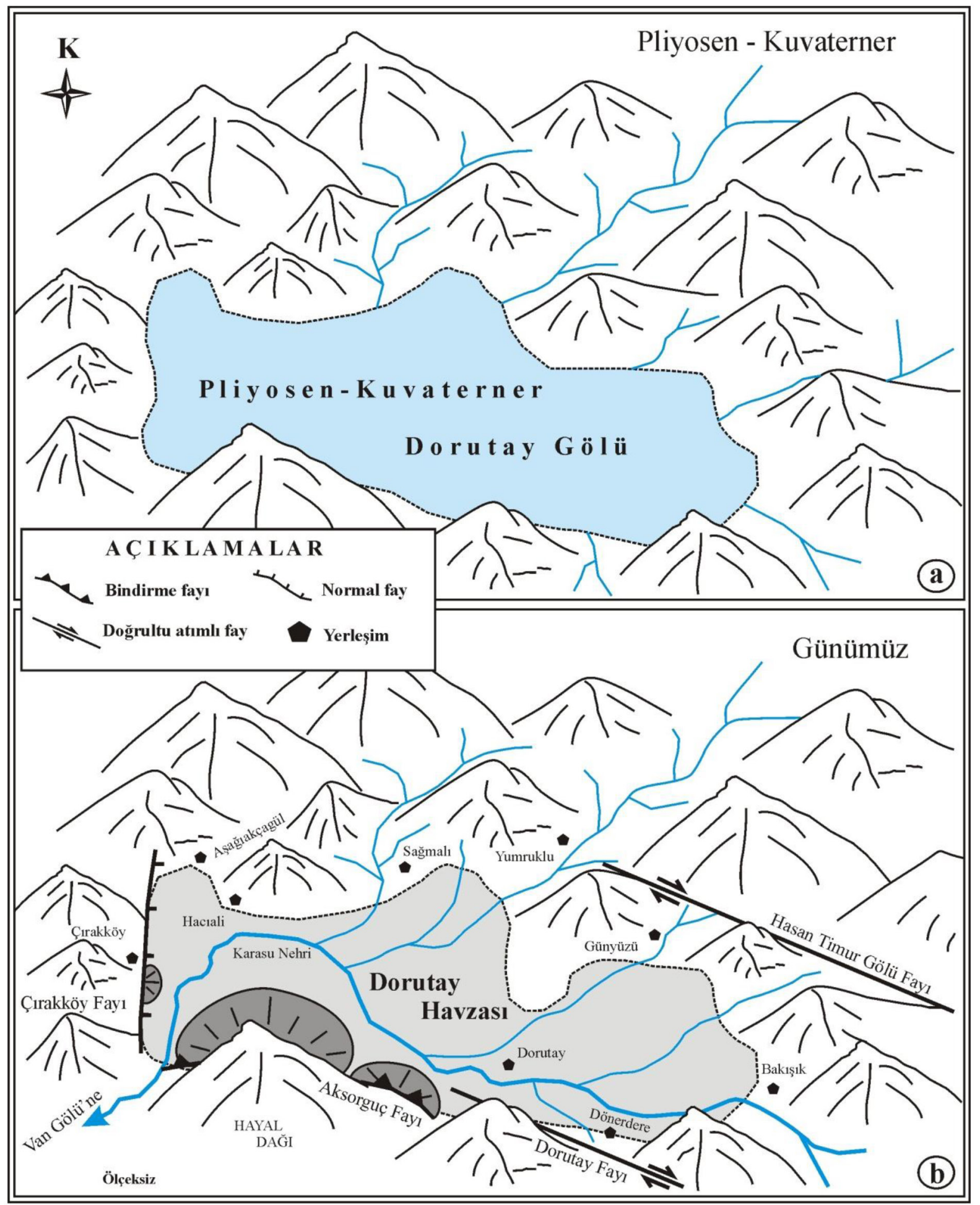

Șekil 6. Dorutay Havzası'nın a) Pliyosen-Kuvaterner ve b) günümüzdeki paleocoğrafik gelișimini gösteren model

Figure 6. Model showing the palaeogeographical development of Dorutay Basin, a) Pliocene-Quaternary and b) Recent. 


\section{KATKI BELIRTME}

Yazarlar değerli görüș ve katkılarından dolayı hakemler ve dergi editörüne teșekkür eder.

\section{KAYNAKLAR}

Altınlı, i̇.E., 1966. Doğu ve Güneydoğu Anadolu'nun jeolojisi. MTA Dergisi, 67, 1-24.

Arni, P., 1939. Van vilayetinin jeolojisi hakkında rapor. MTA Genel Müdürlüğü, Rapor No: 883, Ankara (yayımlanmamıș).

Castelle, B., Bonneton, P., Sénéchal, N., Dupuis, H., Butel, R. ve Michel, D., 2006. Dynamics of wave-induced currents over an alongshore non-uniform multiplebarred sandy beach on the Aquitanian Coast, France. Continental Shelf Research, 26, 113-131.

Degens, E. T., Wong, H. K., Kempe, S. ve Kurtman, F., 1984. A geological study of Lake Van, eastern Turkey. Geologische Rundschau, 73-2, 701-734.

Dewey, J.F., Hempton, M.R., Kidd, W.S.F., Şaroğlu, F. ve Șengör, A.M.C., 1986. Shortening of continental lithosphere: the neotectonics of Eastern Anatolia - a young collision zone, Geological Society of London, Special Publication, 19, 3-36.

Emre, O., Duman, T.Y., Olgun, Ș., Özalp, S. ve Elmacı, H., 2012. 1:250000 ölçekli Türkiye Diri Fay Haritası Serisi, Bașkale (NJ38-6) Paftası, Seri No:55, Maden Tetkik ve Arama Genel Müdürlüğü, Ankara-Türkiye.

Galloway, W. E., 1976. Sediments and stratigraphic framework of the Copper River fan delta. Alaska. Journal of Sedimentary Petrology, 46 (3): 721-737.

Kıraner, F., 1959. Van Gölü bölgesinin jeolojik etüdü. Türkiye Jeoloji Kurumu Bülteni, 7 (1), 30-57.

Koçyiğit, A., Yılmaz, A., Adamia, S. ve Kuloshvili, S., 2001. Neotectonic of East Anatolian Plateau (Turkey) and Lesser Caucasus: implication for transition from thrusting to strike-slip faulting. Geodinamica Acta, 14, 177-195.

Koçyiğit, A., 2013. New field and seismic data about the intraplate strike-slip deformation in Van region, East Anatolian plateau, E. Turkey, Journal of Asian Earth Sciences, 62, 586-605.

KOERI (Kandilli Observatory and Earthquake Research Institute), 2014. Ulusal Deprem İzleme Merkezi, http://udim.koeri. boun.edu.tr, 30 Aralık 2014.

Massari, F. ve Parea, G.C., 1988. Prograditional gravel beach sequences in a moderate to high energy, microtidal marine environment, Sedimentology, 35, 881-913.

Miall, A.D., 1978. Litofacies types and vertical profile models in braided river deposits, a summery. In: Miall, A.D. (ed) Fluvial Sedimentology. Canadian Society Petroleum Geologists Memoir 5, 597-604.

Özkaymak, C., Sözbilir, H., Bozkurt, E., Dirik, K., Topal, T., Alan, H. ve Çağlan, D. 2011. 23 Ekim 2011 Tabanlı-Van Depreminin Sismik Jeomorfolojisi ve Doğu Anadolu'daki Aktif Tektonik Yapılarla İlișkisi. Jeoloji Jeoloji Muhendisliği Dergisi 35 (2), 175-199.

Postma, G., 1984. Slumps and their deposits in fan delta front and slope, Geology, 12, 27-30.

Postma, G., 1990. Depositional architecture and facies of river and fan deltas: a synthesis. In: Coarse-Grained Deltas. (Editors: Colella, A., Prior, D.B.,) Special Publication of International Association of Sedimentology,13-27.

Reineck, H. E. ve Singh, I. B., 1973. Depositional sedimentary environments. Springer-Verlag, Berlin, 439.

Saydamer, M., 1976. İran sınırı boyunca yapılan jeolojik çalıșmanın nihai raporu. MTA Genel Müdürlüğü, Rapor No: 5622, Ankara, (yayımlanmamıș).

Stockhecke, M., Kwiecien, O., Vigliotti, L., Anselmetti, F.S., Beer, J., Çağatay, M.N., 
Channell, J.E.T., Kipfer, R., Lachner, J., Litt, T., Pickarski, N. ve Sturm, M., 2014. Chronostratigraphy of the 600,000 year old continental record of Lake Van (Turkey). Quaternary Science Reviews 104, 8-17.

Sümengen, M., 2008. 1/100.000 ölçekli Türkiye Jeoloji Haritaları serisi, No. 64, Bașkale-K51 Paftası. MTA Jeoloji Etütleri Dairesi, Ankara.

Şaroğlu F. ve Güner Y., 1979. The active Tutak fault, its characteristics and relations to the Çaldıran fault, Yeryuvarı ve İnsan 4, 11-14.
Șaroğlu, F. ve Yılmaz, Y., 1986. Doğu Anadolu'da neotektonik dönemdeki jeolojik evrim ve havza modelleri. Maden Tetkik ve Arama Dergisi, 107, 73-94.

Şenel, M., 1987. 1/100.000 ölçekli Türkiye JeoIoji Haritaları serisi, Bașkale-H38 Paftası. MTA Jeoloji Etütleri Dairesi, Ankara.

Şengör, A.M.C. ve Kidd, W.S.F., 1979. The postcollisional tectonics of the Turkish-Iranian Plateau and a comparison with Tibet, Tectonophysics, 55, 361-376.

Şengör, A.M.C. ve Yılmaz, Y, 1981. Tethyan evolution of Turkey: a plate tectonic approach. Tectonophysics, 75, 181-241. 